\title{
NARRATIVAS (AUTO) BIOGRÁFICAS: SINGULARIDADES POSSÍVEIS
}

\section{(AUTO) BIOGRAPHICAL NARRATIVES: POSSIBLE SINGULARITIES}

\author{
Raquel Alvarenga Sena Venera ${ }^{1}$
}

\begin{abstract}
RESUMO
O presente artigo é parte da análise dos resultados da pesquisa em andamento intitulada "(Auto)biografias e subjetividades: o outro de si mesmo na Esclerose Múltipla", na qual objetiva-se analisar, a partir dos conceitos tempo e memória, os processos de subjetivação das pessoas acometidas pela doença Esclerose Múltipla. A empiria da pesquisa são os discursos (auto)biográficos organizados em redes de Histórias de Vida, visibilizando-as como patrimônios culturais. Essas narrativas fazem parte de um acervo, também em construção, que se somará às mais de 16 mil Histórias de Vida do Museu da Pessoa. São entrevistas coletadas em situação de pesquisa e delas se produzirá um acervo de textos biográficos e material audiovisual. As análises desse artigo fazem parte da elaboração desse acervo e dos procedimentos metodológicos anteriores à elaboração desses textos biográficos. O artigo analisa duas narrativas (auto)biográficas, de um homem e de uma mulher, de 41 anos e 54 anos respectivamente, que vivem com os sintomas da Esclerose Múltipla, há cerca de 20 anos. Destaca-se os processos de singularização, a partir dos fluxos de agenciamentos coletivos de enunciação em que os narradores estão implicados. Essas análises evidenciam o desejo de ser lembrado, mas também o desejo de potência nas experiências com a doença que se apresenta degenerativa com potencial incapacitante. Desejos talhados em um presente com a doença, mas a partir do medo e da insegurança do tempo futuro, das sequelas que são imprevisíveis, que mobilizam tessituras de suas memórias dos passados seguros, anteriores à doença. Em um esforço para refutar o enunciado "superação", as análises apostam nas possíveis singularizações inventadas nas vidas ordinárias, nos processos de subjetivação engendrados nos fluxos dos enunciados mais traumáticos como pode ser um diagnóstico com o da Esclerose Múltipla.
\end{abstract}

Palavras-chaves: Patrimônio Cultural. Memória. Tempo. Singularização.

\footnotetext{
${ }^{1}$ Doutora em Educação pela UNICAMP. Professora da Universidade da Região de Joinville - UNIVILLE. raquelsenavenera@gmail.com.
} 


\section{ABSTRACT}

This article is part of the ongoing research analysis titled "(Auto)biographies and subjectivities: the other himself in multiple sclerosis", which aims to analyze, from the concepts of time and memory, the processes of subjectivation of people affected by the multiple sclerosis disease. The research analyzed empirically were (auto)biographical speeches arranged in networks of Life Histories, giving them visibility as cultural heritage. These narratives are part of a collection, also under construction, which will aggregate more than 16 thousand Life Histories of the Museum of the Person. The interviews were collected in a research situation, and with them we will produce a collection of biographical texts and audiovisual material. The analysis of this article are part of the preparation of this collection and of the methodological procedures prior to the elaboration of these biographical texts. This article analyzes two (auto)biographical narratives, one of a 41 years old man and another of a 54 years old woman, both living with the symptoms of multiple sclerosis for about 20 years. We highlight the singling processes, from the collective arrangements of enunciation streams in which the narrators are implicated. This analysis demonstrates a desire to be remembered, but also the desire of the power in the experiences with the disease that is crippling potential degenerative. Wishes carved in the present with the disease, but with the fear and insecurity of the future time, the sequels that are unpredictable, that mobilize their memories of webbing passed insurance, prior to the disease. In an effort to disprove the statement "overcoming", it bet on the possible singling processes invented in ordinary lives, in the processes of subjectivation in the flows engendered in one of the more traumatic statements as can be the diagnosis of multiple sclerosis.

Keywords: Cultural Heritage. Memory. Life History. Singling Processes. 


\section{Introdução}

O presente artigo é um recorte da pesquisa em andamento, intitulada "(Auto)biografias e subjetividades: o outro de si mesmo na Esclerose Múltipla", a qual objetiva analisar, a partir dos conceitos tempo e memória, os processos de subjetivação das pessoas acometidas pela Esclerose Múltipla em enunciados (auto)biográficos de Histórias de Vida entendidas como patrimônios culturais. Essas narrativas fazem parte de um acervo, também em construção, que se somará às mais de 16 mil Histórias de Vida do Museu da Pessoa. O artigo problematiza, a partir dos conceitos tempo e memória, duas narrativa (auto)biográficas - de uma mulher e de um homem, de 54 anos e 41 anos respectivamente, ambos diagnosticados com Esclerose Múltipla - onde eles se singularizam na medida em que se tornam parte dos fluxos de agenciamentos coletivos de enunciação sobre a doença. Essas entrevistas foram produzidas oralmente, em situações de pesquisa, em seções de entrevistas gravadas em áudio e vídeo.

O caráter interdisciplinar da pesquisa e desse artigo, responde às complexas demandas de uma doença crônica, ainda em fase de investigação das suas manifestações e possibilidades prognósticas, e especialmente ao conhecimento das experiências reais de sujeitos que convivem com essa doença nos dias de hoje. Ainda que a pesquisa dialogue também com os campos da Saúde e Arte Terapia, nesse artigo os conceitos em destaque são especialmente do campo da História como tempo e memória -, e são mobilizados em diálogos com o campo do Patrimônio Cultural e das análises discursivas. Ou seja, o artigo é então parte de um trabalho em que se acredita na potente construção do conhecimento no diálogo com o domínio disciplinar diante de problemas complexos - e nesse diálogo, no lugar "entre" que se cria na sutura de uma disciplina e outra, a interdisciplinaridade se faz. É a vida atravessada pela Esclerose Múltipla, a questão complexa dessas análises e que dispara os diálogos entre os domínios disciplinares.

A Esclerose Múltipla (EM) é uma doença neurológica crônica, ainda sem uma marcação biológica, cujas características são imprevisíveis. É comum que os pacientes relatem diferentes sintomas e essa variação é causadora de uma incerteza bastante grande, ou seja, nunca se sabe o próximo evento. A prevalência do aparecimento da doença é em um momento da vida de muita atividade, entre 16 a 60 anos, no entanto, existem exceções da EM na primeira infância e após os 60 anos. As 
pesquisas de caracterização da EM relatam que seu aparecimento é mais comum entre mulheres e indivíduos da cor branca ou ainda em áreas de clima temperado, além de depender de uma predisposição genética. A EM é entendida como uma doença autoimune na qual o próprio sistema imunológico dirige-se contra vários elementos celulares do sistema nervoso central. As pesquisas no campo da neurologia apontam que os sintomas da EM podem incluir perda de visão, visão dupla, rigidez espástica, fraqueza, falta de equilíbrio, dormência, dor, problemas no controle vesical e intestinal, fadiga, mudanças emocionais e comprometimento cognitivo em diferentes intensidades dependendo do paciente.

Esses sintomas somados a um momento de vida entre os 16 e os 60 anos, em que a família e a carreira estão em desenvolvimento, em que as escolhas são imperativas e especialmente em um contexto contemporâneo de exigências rápidas de expertise no mundo do trabalho, podem trazer aos pacientes significados tão negativas quanto a própria doença. Por isso, ouvir as histórias de vida dos pacientes pode dizer muito sobre a forma como pessoas comuns, homens e mulheres ordinárias, significam a própria vida com uma limitação interna.

Pesquisas no campo da Saúde têm produzido dados inéditos e objetivos sobre a EM, porém, existe uma lacuna no campo das Ciências Humanas apontada no Atlas da EM 2013, evidenciando a ausência de pesquisa relacionadas à qualidade de vida e às experiências de pessoas com EM (MULTIPLE SCLEROSIS INTERNATIONAL FEDERATION, 2013, p. 6). Dessa forma, esse estudo afirma o interesse e a importância desses relatos (auto)biográficos de doentes com EM e persegue a forma como essas pessoas significam a doença nas suas percepções de tempo e como constroem suas subjetividades a partir dessa experiência. Como narram a si mesmos diz respeito a dois registros de conhecimentos articulados e onde esse artigo aposta uma interdisciplinaridade possível: (i) o funcionamento de uma singularização, uma trajetória única de quem vive a experiência da Esclerose Múltipla e (ii) em um processo de subjetivação contemporânea muito mais relacionada com os sentidos sociais disponíveis sobre a doença.

As problematizações, aqui empreendidas foram feitas a partir das narrativas de uma mulher, chamada Nilza Wegner, 54 anos, filha única de um casal de descendentes germânicos, como prefere se apresentar, e de um homem, chamado Ademir Pedro de Souza, 41 anos, primeiro 
filho de um casal como tantos outros que, como narrado por ele, sonham em ter uma família cristã, honesta, modesta e saudável. Neto de alemães fugitivos de uma guerra, como explica sua origem, mas também de ascendência cabocla ${ }^{2}$. A família dos dois entrevistados são moradoras da cidade de Joinville, norte de Santa Catarina. Na época da entrevista Nilza morava com a mãe, chamada carinhosamente de 'Oma', ambas eram aposentadas e possuíam uma cuidadora que organizava e garantia as rotinas da casa. Ademir morava com a família, a esposa e duas filhas, era aposentado e ficava em casa sozinho durante todo dia organizando a rotina doméstica enquanto esperava por elas.

A pesquisa a que está vinculado esse artigo possui um diálogo com a Associação de Apoio aos pacientes de Esclerose Múltipla de Joinville e região, (ARPEMJ), de onde recebe os contatos dos membros ao mesmo tempo em que se articula com a rede de produção de conhecimentos e sociabilidades acerca da EM. Essas duas narrativas (auto)biográficas, foram escolhidas para essas análises porque no momento quando foi lançado o convite para a pesquisa foram os dois primeiros candidatos que apresentaram o sonho de ver suas vidas registradas e publicadas. Desejaram ser os primeiros entrevistados e por alguma razão havia uma pressa que foi aos poucos se explicando.

Em um primeiro momento o artigo apresenta algumas problematizações acerca do trabalho de biografar uma vida ordinária e entendê-las como Patrimônios Culturais. Os diálogos com Paul Ricoeur (1999), Reinhart Koselleck (2014) e Joel Candau (2011) assim como com Félix Guattari; Suely Rolnik (1999) e ainda Agamben (2005). Em um segundo momento apresenta uma síntese das narrativas para em um terceiro momento problematiza-las no contexto das referências teóricas propostas. E, por fim, algumas reflexões provisórias acerca das singularizações orquestradas de formas distintas nas duas vidas narradas.

\footnotetext{
${ }^{2}$ Vale o registro de que a autora possui autorização para uso de seus nomes, imagens e narrativas em situações de pesquisa e publicações de seus resultados. Possui também a aprovação pelo Comitê de Ética em Pesquisa.
} 


\section{Desenvolvimento}

História de um homem é sempre mal contada. Porque a pessoa é, em todo o tempo, ainda nascente. Ninguém segue uma única vida, todos se multiplicam em diversos e transmutáveis homens. (COUTO, 2013, p. 29).

As problematizações a que se propõe esse artigo se iniciam na condição irremediável do fracasso de narrar uma vida. Talvez Mia Couto tenha flagrado esse limite na literatura. Mesmo se houvesse a possibilidade de se ter uma única vida, essa seria maior que uma história, que qualquer narrativa de memória, que todas as tentativas de biografias. Mas ainda assim, "todos se multiplicam em diversos e transmutáveis", e a todo momento é "ainda nascente". O biógrafo de Virginia Woolf também constatou esse fato, e diante do múltiplo que se configura a vida de sua biografada ele propõe um trato honesto com seu leitor:

Tendo em mente os limites da biografia, a escassez do que podemos saber sobre qualquer ser humano e as vastas áreas que permanecem no escuro, prometi respeitar tudo o que há do outro em meu tema, ouvir o que Virginia Woolf realmente disse, não o que se esperaria que ela dissesse (MARDER, 2011, p. 31).

François Dosse (2009) considera a ideia de "ilusão biográfica" de Pierre Bourdieu (1986), mas recusa a forma como ele invalida a pertinência da autoria no processo histórico do sujeito que se narra. Leonor Arfuch (2010) vai nessa direção e atenta para o fato de que essa percepção de vida e da identidade em um contínuo, em uma unidade apreensível e transmissível é necessária "para a (própria) vida e para a afirmação do eu", no entanto, esse fio que se move em direção à ilusão biográfica deve-se tornar consciente para o pesquisador. (p. 254-255).

Esse texto concorda como essas ponderações e, diante da ilusão de chegar à totalização de uma vida, a impressão de que, ao acessar a memória dos biografados, se acessa também o passado vivido e a vida como ela foi, se propõe iniciar o artigo assumindo-se o fracasso dessa intenção e a certeza de que o que se tem é apenas uma ilusão, um espectro e nem por isso se invalida as narrativas (auto)biográficas dessa empiria.

E diante dessa afirmação, uma segunda problematização - por que, então, biografar? Essa questão não é nova. François Dosse, trabalhou exaustivamente sobre ela na obra "O desafio biográfico: escrever uma 
vida" (2009). Sob várias formas de biografar ao longo do tempo, em vários campos do conhecimento, biógrafos biografaram sob uma razão, uma intenção, e diferentes metodologias. Mas, no fundo de cada desejo biográfico existe um jogo de espelho, de construir-se a si mesmo, que se inicia na empatia necessária da escolha do biografado e se projeta na tessitura da construção do "ele" em camadas com um "eu". Nas palavras de Dosse, "no desejo de construir-se e definir-se como um Eu, de ser, na plenitude do termo, uma Pessoa" (2009, p. 14).

No entanto, essa projeção não é um privilégio apenas das pesquisas biográficas. Elas são próprias das pesquisas nas ciências humanas e sociais que assumem que o distanciamento objetivo se mantém em meio-termo diante das investidas passionais que disparam o pesquisador ao seu objeto. Essa afirmação também não é nova. Boa Ventura de Souza Santos falava dela ainda na década de 1980, quando argumentava em favor de uma ciência posta em diálogo entre as ciências naturais e as ciências sociais. Uma ciência onde o autor, pesquisador e sujeitos do mundo estariam no centro do conhecimento, sem nenhuma essência de natureza, mas capaz de criar inteligibilidades, conceitos que derretam as fronteiras que a ciência moderna instituiu com a lógica matemática do método. Uma produção do conhecimento que se assume subjetiva sem perder de vista a objetividade científica do método.

E uma terceira problematização vem da questão: por que então biografar pessoas comuns, ordinárias? Esse artigo possui um compromisso político com a afirmação de que as Histórias de Vidas são Patrimônios Culturais. O historiador Dominique Poulot ao historiar o campo do Patrimônio no Ocidente sugere haver três imaginários sobre o patrimônio, como o "lugar da pessoa pública, em particular a figura do rei, lugar da história edificada, lugar da identidade cultural" (POULOT, 2009, p. 14). No Brasil, a virada desse imaginário se deu após a segunda abertura política brasileira, 1985, e por consequência a Constituição Federal de 1988. Em seu Artigo 216 refere-se ao patrimônio como bens corpóreos ou incorpóreos, vistos de forma individual ou coletiva, de natureza material ou imaterial. O patrimônio ganha sentidos mais amplos relacionados ao exercício da cidadania e a expressão da democracia. Poulot anuncia que:

Na virada do século XX para o XXI, o patrimônio deve contribuir para revelar a identidade de cada um, graças ao espelho que ele oferece de si mesmo e ao contato que ele permite com o outro: o outro de um passado perdido e como se tornado selvagem; o 
outro, se for o caso, do alhures etnográfico (POULOT, 2009, p. 14).

Nesse aspecto, esse contexto não marcou apenas uma virada de século, mas uma "virada" nos sentidos que estavam em disputas no campo. E é essa "virada" nos agenciamentos coletivos de enunciação relacionados ao Patrimônio que importa para essas análises. As pesquisas nesse campo vêm sendo cada vez mais acionadas tanto pelas políticas de cultura que tem na UNESCO - a principal defensora de "ações em favor do patrimônio", tornando-o "frequentemente, a vanguarda de uma democratização cultural” (POULOT, 2009, p. 201) -, quanto pelos Estudos Culturais que oferecem respaldos epistemológicos em defesa de uma vocalização testemunhal das minorias e dos mais diversos grupos, mas também, e principalmente, de problematizações sobre a frenética, e por vezes essencializadora, patrimonialização em um mercado de passados. Andreas Huyssen tem sugerido caminhos para pensar como privilegiamos alguns passados e memórias e ao mesmo tempo somos impactados pela mídia e suas possibilidades de percepção veloz do tempo. E nessas reflexões o autor se pergunta: "por que? Por que agora? Por que essa obsessão pela memória e pelo passado e por que este medo do esquecimento? Por que estamos construindo museus como se não houvesse mais amanhã?" (HUYSSEN, 2000, p. 20) E amplia o debate acerca da ética e política necessários ao campo da memória em um tempo em que se comercializa traumas, tanto quanto uma diversão. Ao mesmo tempo em que grupos reivindicam a memória dos seus ascendentes, externando de forma militante o desejo de patrimonialização, os traumas - como o Holocausto por exemplo, assombram as sociedades atuais, questionando a crença no progresso da modernidade -, essas mesmas memórias de dor tornam-se mercadoria espetacularizadas em filmes, museus, documentários, sites na internet, livros, HQs, e até motivos de souvenires para turistas. "Trocando em miúdos: o passado está vendendo mais do que o futuro" (p.24).

Ainda no mesmo campo, mas em consonância à defesa da vocalização das minorias, os estudos especialmente de Paul Thompson (2006) têm argumentado a favor da História de Vida como patrimônio da humanidade, ou seja, ao encontro das tendências das pesquisas no campo da História, a chamada História Oral, segundo ele:

[...] é considerada atualmente parte essencial de nosso patrimônio cultural. Essa é uma situação muito nova e, olhando para o futuro, acho que há possibilidades imensas, por exemplo, para criar 
novas conexões entre as pessoas em mundos sociais e geográficos diferentes; através do oral, criando novas solidariedades e novos entendimentos (THOMPSON, 2006, p. 19).

Desta forma, em consonância a esse conceito ampliado de patrimônio cultural, o trabalho de biografar Histórias de Vida de pessoas comuns se consagra nas contingências internacionais no campo do Patrimônio, propostas pela UNESCO, quais sejam, a democratização cultural em defesa da garantia das vozes dos grupos e de seus diferenciais que até a primeira metade do século XX não eram incluídas no que chamamos bens culturais patrimoniáveis.

Então, diante da primeira problemática apresentada - se uma vida em sua totalidade não se dá a biografar, se haverá um cuidado em considerar apenas o que foi dito e se deu a revelar nas (auto)biografias -, e diante da segunda problemática - se existe um jogo assumido de empatia do biógrafo e o biografado -, assume-se também, a terceira problemática que há um pouco ou muito pragmatismo nessas análises anteriores às biografias. E nesse exercício há um acordo com François Dosse (2009), "Pouco se nos dá então que a personagem seja grande ou pequena, pobre ou rica, inteligente ou medíocre, honesta ou criminosa - todo indivíduo só vale por aquilo que o singulariza" (p. 57).

E foram os processos de singularização o foco a ser perseguido desde a elaboração do roteiro das entrevistas da pesquisa. Concorda-se com Ricoeur (1999) que as narrativas de memória são confeccionadas a partir das diversas lembranças que são evocadas. Entende-se que o narrador possui autoria e soberania nessas escolhas de lembranças que o entrevistador só tem acesso com seu consentimento. No entanto, as lembranças permitidas são evocadas a partir de estímulos organizados pelo entrevistador. As experiências vividas em um presente direcionam as re-elaborações da memória sobre o passado - esse pensamento domina, em grande medida, os direcionamentos epistemológicos sobre a memória, interpretados pela ciência História e muito potente para pensar o Patrimônio Cultural. Nesse artigo, conceitualmente o tempo e a subjetividade são evocados a partir da experiência com a EM - uma doença incapacitante e ameaçadora da perda da faculdade humana de memorar. Ou seja, assume-se um local de releitura bastante marcado pelas emoções da perda, pelo desejo de resistência e pela experiência existencial com a identidade a partir da memória. E procura-se singularizações a partir dessa experiência. Entende-se identidade não 
como o prefixo da palavra sugere: um "idem" fixo como se fosse alguma essência humana a ser perseguida, mas algo muito mais móvel e intercambiável nos fluxos dos agenciamentos coletivos de enunciação. São subjetividades em processos contínuos no tempo.

Nessa direção é Zygmunt Bauman que nos inspira ao dizer que uma identidade não se constrói como um quebra cabeça, com a junção de peças em lugares certos com fim na construção de uma imagem projetada como caminho a ser percorrido. Não existe uma essência primordial, uma imagem primeira para seguir como objetivo, mas ao contrário, ele explica:

\begin{abstract}
No caso da identidade, não funciona nem um pouco assim: o trabalho total é direcionado para os meios. Não se começa pela imagem final, mas por uma série de peças já obtidas ou que pareçam valer a pena ter, e então se tenta descobrir como é possível agrupa-las e reagrupa-las para montar imagens (quantas?) agradáveis. Você está experimentando com o que tem. Seu problema não é o que você precisa para "chegar lá", ao ponto que pretende alcançar, mas quais são os pontos que podem ser alcançados com os recursos que você já possui, e quais deles merecem os esforços para serem alcançados (BAUMAN, 2005, p. 55).
\end{abstract}

Por essa razão decidiu-se trabalhar além da memória e subjetivações também a percepção ou consciência temporal. Concordando com Paul Ricoeur (1999) quando ele aproxima e até mesmo funde a memória ao tempo. Para o autor, "la memoria garantiza la continuidade temporal de la persona"” (RICOEUR, 1999, p. 16), e essa ideia apresenta parte da afinidade conceitual acerca da memória e do tempo desse artigo. Concorda-se com o autor quando ele separa memória e lembrança que se organizam em níveis de sentido como "archipélagos separados posiblemente mediante precipícios" ${ }^{4}$ (RICOEUR, 1999, p. 16) e as narrativas de memória, a partir de uma demanda de um tempo presente, "sigue siendo a capacidade de recorrer y de remontar el tiempo, sin que nada em principio pueda impedir que continue sin sulución de

\footnotetext{
3 Tradução livre para o português “a memória garante as continuidades temporal da pessoa".

4 Tradução livre para o português "arquipélagos possivelmente separados por precipícios".
} 
continuidade ese movimento ${ }^{5 "}$. (RICOEUR, 1999, p. 16). E, dessa forma, as sensações de existência se ligam ao fio de uma vida que possui vínculos geracionais a um passado e horizontes de expectativas de futuros.

A afirmação de que tempo é memória produz um sentido surpreendente ao próprio tempo que se faz ver a partir dos gestos narrativos que organizam as lembranças em um fluxo entendível. A EM, por ser uma doença altamente incapacitante, sem uma marcação biológica, portanto imprevisível, sem cura e ainda de difícil interpretação médica, interfere na organização temporal do paciente. O presente é marcado pelas demandas e experiências físicas com a doença, seu futuro, ou melhor, suas expectativas de futuro são insertas e obscurecidas pelo medo de diferentes sequelas, incluindo a inexistência causada pela perda da memória e, o que resta de mais seguro são as memórias do passado, da vida vivida sem a doença.

Nesse aspecto é possível afirmar que existe uma experiência temporal comum entre os pacientes? É Reinhart Koselleck (2014) que ajuda pensar a questão. Ao analisar as memórias da guerra ele oferece ferramentas de análises possíveis para perscrutar as subjetividades produzidas nesse jogo de consciência/percepção temporal. Segundo ele "a biografia de qualquer ser humano contém rupturas que parecem abrir um novo período na vida" (KOSELLECK, 2014, p. 247) e as experiências bruscas forçam o sujeito a abandonar caminhos comuns e abrir novas possibilidades. Ele dizia sobre a guerra, mas analogicamente essas análises nos ajudam a pensar a EM, uma doença rara, crônica, sem cura, degenerativa e incapacitante como outra experiência brusca. A ideia das "eclusas da memória" que o autor mobiliza será melhor trabalhada na metodologia dessa pesquisa, aqui, porém, ela apenas amalgama a experiência temporal a partir da doença com as releituras dos conceitos memória e a subjetividades.

O diálogo com Koselleck amplia as possibilidades de percepção do tempo em uma História de Vida que em grande medida é marcada pela linearidade do começo da vida orientada pelo nascimento, origem da família, infância, juventude, vida adulta... até o presente. Mas a problematização dessa orientação linear, destacando a multiplicidade de

5 Tradução livre para o português "segue sendo a capacidade de recorrer e de reconstruir um tempo, sem que nada pode impedir que se solucione a continuidade movimento" 
tempos em um mesmo tempo, é potente no argumento de que as narrativas de memórias de vida se iniciam a partir da demanda trazida pela ameaça da perda da memória, ou seja, pelo presente. Dessa forma entende-se que o fio latente da origem da história da vida coincide com o lugar de luto deixado pela doença e não pelo nascimento. Isso significa dizer que lembrar o passado, tornar o passado presente, só importa a partir de demandas existenciais do presente tendo em vista as expectativas de futuros também no presente.

Para encaminhar as análises a favor das Histórias de Vida como Patrimônios Culturais, faz-se necessário conhecer a sensibilidade temporal dos sujeitos da pesquisa no intuito de mobilizá-la à organização das memórias da sua própria História. Joel Candau argumentou que a aprendizagem sobre o mundo, sobre a cultura de um grupo se faz a partir de certa transmissão de memórias, que poderiam ser também entendidas como experiências do grupo. A aprendizagem de que a "adaptação do presente ao futuro organizada a partir de uma reiteração do passado" (2011, p. 106) levaria à construção de uma identidade. $\mathrm{O}$ autor problematiza os argumentos essencialistas da memória e da identidade e radicaliza a favor de arranjos sociais da memória e da identidade. O que lembrar? o que esquecer? o que privilegiar? e descartar em um grupo social? Perguntas que fazem parte do jogo político, dos arranjos da memória.

Em especial, se mostram potentes os estudos acerca das memórias familiares e reapropriações dessas memórias pelas gerações que, segundo o autor, vão desencadeando o que ele chama de "totalização provisória de seu passado", que é o arranjo da construção da identidade e alteridade do sujeito que memora. É nesse arranjo que os sujeitos fundam uma narrativa de existência e se sentem pertencer a uma cadeia de gerações sucessivas da qual o grupo ou o indivíduo se sente herdeiro. Usando as metáforas de um jogo, pode-se dizer que existe uma sensação de certeza de um vínculo com um passado e uma perspectiva de futuro que o impulsiona no presente a jogar no jogo da memória e da identidade. A História de Vida de pessoas acometidas pela EM pode ser entendida como um ousado alcance nesse tabuleiro da memória. Nessa perspectiva individual a memória e a identidade podem ser entendidas nos espaços reduzidos das articulações familiares, no desejo de participar desse constructo familiar de memórias. No entanto, nos estudos acerca da memória também coletiva, em arranjos muito mais complexos novas perspectivas são consideradas nesse arranjo 
identitário. Existe um grupo social maior que a família que comunga de experiências semelhantes àquelas narradas em Histórias de Vidas. Joel Candau ao expor resultados de pesquisas com memórias de pessoas que experimentaram tragédias vincula à capacidade dessas memórias de agregar os semelhantes ou repelir os opostos. Esse artigo entende que os gestos de organizar as lembranças em formas narrativas de memórias, priorizando o que deseja pôr-se a saber também pode ser entendido nos fluxos de agenciamentos onde se fazem os processos de subjetivação.

Os diálogos com Félix Guattari e Suely Rolnik (1999) contribuíram para essa releitura e colocam a cultura de massa como máquina de produção. Trata-se de terminais onde a cultura opera. Ou seja, as pessoas acometidas pela EM, no momento do diagnóstico, entram também em contato com uma série múltipla de informações sobre a doença e sobre os doentes. Consome-se os discursos acerca da doença, das pesquisas, das maneiras de viver com a doença, mas em outras "eclusas" no tempo de suas vidas consumiam outros enunciados que não estão desconectados a todos os outros no decorrer da vida de forma que quando narram suas histórias trata-se de um rizoma de lembranças que se forma.

Nesse ponto, para pensar essa tessitura, as análises têm recorrido à obra de Giorgio Agamben (2005), intitulada "Infância e História". O autor coloca uma questão em discussão que se mostra fundamental para a construção dessa ferramenta: se um ser possuísse uma experiência de linguagem de apresentar-se desde sempre como falante e possuísse sempre uma língua comum a todos os indivíduos, "ele seria desde sempre imediatamente unido à sua natureza linguística e não encontraria em nenhuma parte uma descontinuidade e uma diferença nas quais algo como o saber e uma história poderia produzir-se" (AGAMBEN, 2005, p. 14). O exemplo é hipotético e impossível; o primeiro movimento de aquisição da linguagem pelo sujeito falante e, portanto, a relação entre o pensamento e a linguagem cindida em língua e discurso carrega, em sua natureza, as descontinuidades da falta ou da privação marcadas pela história e pelo conhecimento.

Existe concordância, então, com a existência no limiar transcendental entre língua e discurso, em que o autor localiza o que ele chama de "morada infantil". O conceito de infância de Agamben talvez evidencie a presença constante do "processo de individuação" proposto por Guattari e Rolnik. Para Agamben, a infância não seria um tempo 
cronológico na vida dos homens e das mulheres, seria na verdade uma tentativa de pensar o problema dos limites da linguagem. O diagnóstico da doença oferece momentos dessa "morada infantil" do puro signo. Ainda que haja uma imensidão de informações acerca da doença, ainda que essas informações interpretem em grande medida o vazio que produz o diagnóstico, há um luto indecifrável, um momento de infância com a ausência de tradução.

A busca da infância, por meio da linguagem, é sempre constante e as experiências com a EM oferecem esses lapsos de vazios interpretativos. Jogar com os sentidos e signos, fazer funcionar os sentidos da língua é deparar, por relampejos, com a infância. Inserindo Agamben em diálogo com Guattari e Rolnik (1999) e considerando o movimento em que o indivíduo é interpelado pela "produção de subjetivação", esses momentos de infância, de interpretação dos vazios que a doença traz é como um novo lócus nos fluxos de agenciamentos que vão produzindo novas maneiras de perceber, de sentir o mundo, ao mesmo tempo em que, também, se fabrica estéticas de vida, possibilidades que são consumidas por outros doentes, como se fosse um mercado de cultura e formas de vida. Os autores sugerem máquinas de "produção da subjetividade", que, segundo eles, podem variar conforme a necessidade dos sistemas culturais (GUATTARI, ROLNIK, 1999, p. 25).

Essas análises têm a intenção de sair da lógica da representação e posicionar a micropolítica, possibilitando pensar para além da linguagem enquanto sistema que nomeia as coisas, que representa o exterior a elas como um conjunto de significantes que compõem em uma estrutura geral. Para sair dessa limitação do conceito tradicional de linguagem, tem-se optado não falar em "agenciamento coletivo de enunciação". Assim, assume-se um campo de "subjetividades políticas", e este pressupõe uma multiplicidade de agenciamentos. Seria coerente pensar que nesse campo coexiste: a) a infância (AGAMBEN, 2005) aquele sujeito que fala e estará sempre deparando com a experiência babélica de novos signos de sua cultura ou estará sempre convivendo com a privação da linguagem; b) o indivíduo seriado (GUATTARI, ROLNIK, 1999) - produzido pelas máquinas capitalísticas e, ao mesmo tempo, disciplinado pelas instituições estatais, que provocam individuação do corpo, capaz de fixá-lo como terminal consumidor; e c) um campo de subjetividades marcadas pelas necessidades do tempo histórico vivido e modeladas no registro do social. 
Esses pensamentos tornam-se ferramentas que permitem interpretar as subjetividades que agenciam enunciados em dois movimentos possíveis. No primeiro, essa subjetividade permanece submetida à subjetividade tal como a recebe, assumindo a "alienação e opressão", como também proposto por Guattari e Rolnik (1999). No segundo movimento, ela se reapropria dos componentes da subjetividade, valendo-se da expressão e da criação, e vive o "processo de singularização". Esses dois movimentos são intercambiáveis em um mesmo corpo e "duplamente descentrados". Considerando essa descentralização constante, pode-se afirmar que o segundo movimento - "processo de singularização" - é imanente ao primeiro movimento "processo de subjetivação". Essa imanência justifica a preferência conceitual dos autores entre ideologia e produção de subjetividades. Ao trocar o conceito tradicional da linguagem por "agenciamento coletivo de enunciação", Guattari e Rolnik (1999) estão considerando que, os pontos de singularidade em processos de singularização são as próprias raízes produtoras da subjetividade em sua pluralidade. A singularização seria a utilização da potência humana de negociar sentidos no limiar da privação da língua, no local das tensões entre o signo e a semântica, entre o saber e o movimento da história.

\subsection{Duas narrativas de vidas com Esclerose Múltipla}

\subsubsection{Nilza Wegner}

Nilza nasceu em 15 de outubro de 1961 em um bairro de Joinville onde ainda era possível manter criações de animais, como vacas. Faz questão de contar sobre os cuidados que recebeu na infância, que a mãe ficou com ela durante os primeiros dois anos de vida, e depois, mesmo que precisasse voltar ao trabalho como doméstica, levava-a e estava sempre atenta. Sobre o pai, ela se lembra de um homem bonito, que trabalhava muito, era brincalhão e lhe trazia muitos presentes. Todos que ela desejava. Nilza cresceu visitando a casa dos avós, brincando e brigando com os primos e frequentando a igreja Luterana. Ao mesmo tempo, narra também pequenos acidentes domésticos que lhe aconteceram, e sobre esses, marca uma narrativa da mãe responsabilizando o pai e vice versa. Em sua narrativa existe ao mesmo tempo o destaque para um cuidado e a presença de uma rigidez muito grande na educação e na construção de disciplina. 
Medidas disciplinares que ela tratou de transgredir, mais ou menos na mesma época em que fez a "confirmação" na igreja e quando começou com as paqueras com os meninos. Nilza narra-se uma moça bonita, desejada pelos rapazes. Os pais não aprovaram seu primeiro namorado - por ser filho de pais separados e de descendência italiana -, mas ela tratou de se firmar com um segundo pretendente, de "origem alemã", mesmo que ex-namorado de uma amiga. Sob o aceite dos pais, os passeios com os amigos de moto, as aventuras passaram a fazer parte da sua vida. Ela disse desejar viver uma liberdade nunca antes experimentada. Os registros fotográficos dessa história de amor e liberdade foram socializados durante as seções de entrevistas como um trunfo de um passado feliz e desejado. Uma juventude adjetivada como "rebelde", mas ao mesmo tempo, narrada com muito sentido de liberdade e força vital.

Nilza não terminou os estudos na universidade, segundo ela, sua concentração era no namoro. Com a formação em "técnico em contabilidade", pode trabalhar em escritórios. Casou-se com o namorado de "origem alemã" e foi morar com os pais, mas a disciplina e as regras da casa nunca mudaram e assim que suas condições no trabalho melhoraram ela financiou uma casa. Foi mãe de dois filhos e contou com a ajuda da sogra para cuidar do primeiro bebê. Mas, depois da segunda gravidez deixou o trabalho remunerado e se dedicou aos afazeres domésticos e aos cuidados das crianças. Ela narra com arrependimento um afastamento dos seus pais e uma aproximação muito intensa com a família do marido. Ao lembrar-se da sua relação com seus filhos também se arrepende por ter sido tão rígida, tão exigente e enxerga no pai das crianças o papel maternal de afeto, de carinho e explicitação de amor. Ela conta que os filhos na fase escolar, como muitas outras crianças, frequentavam além da escola, o movimento escoteiro e a igreja Luterana.

Logo que as crianças cresceram, a inquieta Nilza montou uma estamparia que funcionou inicialmente no mesmo endereço de sua casa. Esse empreendimento deu muito certo e se transformou em uma facção terceirizada da Benetton, que funcionava das $5 \mathrm{~h}$ da manhã às $10 \mathrm{~h}$ da noite, com costureiras trabalhando em turnos. Ela se transformou em uma pequena empresária e narra esse momento como um momento de ânsia pela riqueza, exercitando toda a sua destreza, agilidade, exigência de perfeição na produção e muito estresse. Foi um momento também de crises no casamento, desconfianças de traições e o aparecimento dos 
primeiros sintomas da Esclerose Múltipla. Nesse momento, ela diz 'não tinha Nilza', eu não pensava em mim, era só trabalho, trabalho, trabalho.

A busca pelo diagnóstico, as limitações físicas vieram ao mesmo tempo que uma crise no trabalho do marido em uma fábrica têxtil da cidade e a volta para a dependência financeira dos pais. Desta vez, sem uma renda e com o marido desempregado, o pai de Nilza que nunca tinha se relacionado bem com o genro, exigiu que ele se retirasse da relação. Com um entendimento claro de que se o homem deveria ser o provedor da família, e ele não conseguindo garantir nem o plano de saúde para a filha, não deveria mais fazer parte da casa. O marido, dizendo não aguentar mais aquela situação imposta se retirou para sempre. Assim, diagnosticada com EM, em um tempo em que não haviam medicações disponíveis, limitada para desenvolver suas atividades de empresária, foi acolhida pelos pais, mas sofrendo também com a perda de um grande amor. Magoada com os pais ao mesmo tempo em que se tornou totalmente dependente deles. Hoje, seu pai já é falecido, e mesmo que tenha tentado se manter em sua casa com seus filhos, esses saíram para casar e restou a ela convidar a mãe para dividirem a mesma casa e a mesma cuidadora. $\mathrm{O}$ ex-marido já em outro relacionamento, nunca mais foi bem-vindo à sua casa e paga uma pequena pensão depois de uma briga judicial. Uma das sobrinhas dele é a sua cuidadora há 11 anos e somente seu sobrenome já causa insatisfações da 'Oma'. Eles são avós de três crianças, ela percebe o filho mais velho no seu antigo ritmo, com muito trabalho, muito estresse e desejo de conquistar riquezas e com pouco tempo para atenções à família. O mais novo, a visita todos os dias, a coloca para dormir todas as noites e com um beijo se despede.

Nilza nos recebia em sua casa com apreço, escolhia o quarto como o espaço onde se sentia mais segura para as entrevistas, perto do computador onde guardava alguns registros do passado. No início mais tensa, com uma narrativa mais regulada, visivelmente o desejo de controle da própria entrevista, mas depois que um vínculo com a equipe foi se firmando, e com mais segurança, se permitiu sair do quarto, usou os espaços externos da casa. Expressou-se com dificuldade para articular uma sequência temporal, por vezes com pequenos lapsos de memória, mas consciente da sua dificuldade pedia ajuda para a mãe, pedia para buscar pequenos registros escritos em folhas de papéis. Folhas já com marcas de muito uso, dobras rasgadas, sinais da tentativa desesperada de evitar a perda de lembranças. Seus registros e guardados eram um ajuntamento desorganizado de dados, mas que ela se atinha na 
ânsia de oferecer informações mais precisas. Nilza tem o hábito de registrar pequenas informações como datas de consultas que foram importantes para ela, tais como a primeira vez que fez uso de uma medicação, quando sofreu efeito colateral, quando fez troca de medicação, datas do casamento, confirmação das crianças, boletins escolares, entre outros documentos de família. Enfim, ela não quer perder as lembranças.

\subsubsection{Ademir Pedro de Souza}

Ademir Pedro nasceu em 22 de fevereiro de 1974, é o primeiro filho de um casal como tantos outros que sonham em ter uma família cristã, honesta, modesta e saudável. Como a família de Nilza, sempre foram moradores de Joinville, mas atualmente apenas ele mora na cidade, os demais estão em uma casa na praia. $\mathrm{O}$ casal teve Ademir ainda muito jovem e logo depois a irmã caçula. Ele se emociona em lembrar dos carinhos da mãe, do colo que ainda parece quente em suas lembranças. Essas lembranças "são azuis", ele diz, a cor que metaforicamente o acaricia enquanto lembra. O pai, ele admira por ser "um homem que nunca reclama de nada", com preceitos de honestidade e verdade que marcaram a vida do filho. Conta o pouco que sabe da sua ascendência híbrida, dos bisavós alemães, dos avós miscigenados e dos pais estereotipados como brasileiro.

Ademir lembra que a família viveu um problema de saúde bastante sério com a irmã, ainda quando muito bebê. Ele se recorda do padre em casa e de todos esperando a morte da criança, lembra dos pais chorando muito e dos seus sentimentos confusos. Mas ao narrar esse episódio ele reforça os laços da família, a amizade verdadeira entre eles ainda hoje. É uma lembrança que vem no contexto de afetos diante da quase perda da irmã e da percepção infantil da importância da família e reforça que, no presente, apesar de morarem em outra cidade, estão em contatos virtuais todos os dias. Como outros moleques da sua idade, brincou na rua com os vizinhos, jogou bola na quadra do bairro, fez peraltices que o pai só veio saber muitos anos depois. Iniciou no mundo do trabalho ainda muito jovem contra a vontade do pai, que desejava que ele terminasse os estudos. Mas o desejo de consumir, como os amigos mais velhos, o colocou em uma fábrica metalúrgica aos 15 anos. Em seguida descobriu o trabalho no comércio, em uma autopeças, e se realizou vendendo peças 
de carros e conversando com clientes. Na adolescência saia para dançar, para paquerar e seus olhos azuis faziam sucesso e foi entre essas experimentações que conheceu sua esposa - mulher a quem atribui o seu grande amor. Antes dos 20 anos ele descobriu uma grande paixão e lembra com doçura o tempo em que saiam de moto com outros casais de amigos para a beira do rio na área rural de Joinville.

Foi com essa mulher que, também muito jovem, foi pai de duas filhas e ao lado dela construiu seu patrimônio. A gravidez da namorada acelerou o casamento e a princípio, morou nos fundos da casa do pai, depois comprou um terreno em um bairro mais afastado do centro e foi construindo uma casa aos poucos. Sobre esse passado lembra que se sentia muito seguro de si, gostava de andar de bicicleta, era ágil e desejava ter seu próprio negócio. Morou dentro da construção, trabalhou sem limites e terminou a casa.

Foi logo depois do casamento, em meio a essa construção inicial da vida, que ele começou sentir os sintomas da Esclerose Múltipla, mas ficou sem o diagnóstico por dez anos. Caia sem entender o porquê, tinha dificuldades para pedalar a bicicleta, sofria com fadigas nas noites de verão na casa em construção, "que era um forno", ele conta. Não entendia por que sentia mais calor que os outros, formigamentos pelo corpo e uma sequência de noites mal dormidas. Sentia que não tinha mais velocidade e equilíbrio na loja de auto peças onde trabalhava e frequentemente deixavam as peças cair, quando ele mesmo não caia. Sentia-se por vezes humilhado entre os colegas de trabalho que por vezes diziam que ele estava bêbado. Mesmo com tantas dificuldades terminou a casa e montou seu próprio negócio. Mas as coisas não foram bem e, fragilizado, não conseguiu ser o empresário de sucesso com o que sonhou até vender a loja e se tornar novamente um funcionário.

Passou por muitos médicos, fez numeráveis exames e recebeu alguns diagnósticos que levaram a terapias ineficazes. Até que veio o diagnóstico que foi significado como um alívio. Ele ouve falar de diagnósticos que funcionam como um "divisor de águas" na vida das pessoas, mas na sua história o diagnóstico funcionou como um "grande alívio", afinal ele precisava de uma explicação para tantos limites em um corpo tão jovem. Dois anos depois Ademir se aposentou e, no momento da entrevista morava nessa mesma casa que foi construída com tanto esforço, com a esposa e as duas filhas. Uma delas estava noiva e ele se orgulhava com o início da sua vida adulta, com a compra de um 
apartamento próximo ao endereço da família. As três mulheres da sua vida trabalhavam durante todo o dia e ele fica em casa cuidando vagarosamente de cada detalhe. Por vezes protagonizava algum acidente doméstico, mas enquanto se narra não se vê dependente de cuidador. Metódico, sistemático ele cuida do jardim, do quintal, da casa e principalmente da cozinha onde recebia a equipe para as entrevistas com muito agrado. Faz da cozinha seu lugar de prazer e cuidado da família. É ali que agrada as filhas e a mulher quando prepara as tapiocas do café da manhã, a batata doce para a filha, as experimentações de receitas que ele descobre em um canal de TV ou na internet. Ademir inventa receitas com as frutas do quintal e faz dos bolos e pratos que prepara a alquimia da própria vida.

\subsection{Operação do tempo e memória}

Nilza e Ademir possuem o sonho de escrever um livro sobre as suas vidas e esse desejo veio depois da EM. Foram as experiências com as perdas que dispararam a ânsia pelo registro de si mesmo. Quando ela recebeu o convite para participar da pesquisa se ofereceu prontamente para ser a primeira entrevistada, seguida por ele. Ela tem pressa desse registro, as suas lembranças se perdem. Ele desejou visibilizar um tempo antes da doença, mas também e especialmente comunicar um tempo de gratidão à família após o diagnóstico.

O tempo dessas duas vidas se materializou na medida em que as narrativas de memória se processavam. Durante as narrativas de Nilza, os fragmentos guardados em pedaços de papel como datas e pequenos fatos importantes funcionaram como garantia de lembranças que lhe faltaram na tessitura da memória. Essa análise concorda com a afirmação de Paul Ricoeur (1999) que tempo é memória e essa produz uma visibilidade ao tempo narrado, e se atenta também para o tempo linguístico anunciado por Arfuch (2010) quando diz que o tempo que se desdobra no ato da enunciação se faz na medida em que se tem subjetividades correlacionadas em um presente atual. As narrativas de memória tanto da Nilza como do Ademir só se fizeram possíveis porque o "hoje" era compartilhado por quem contava, o "eu", e por quem ouvia, o "outro", e isso garante uma "refiguração de nossa experiência pelo tempo construído no relato" (ARFUCH, 2010, p. 115) de forma que o 
autor da narração se faz como um outro de "si mesmo" tempo compartilhado.

A EM, por ser uma doença altamente incapacitante, sem uma marcação biológica, portanto imprevisível, sem cura e ainda de difícil interpretação médica, interfere na organização temporal do paciente. Os dois entrevistados sentem a vida a partir da lentidão dos limites físicos. Vivem no ritmo dos limites físicos, ela com sua cadeira de rodas e ele com uma muleta, no entanto, constroem uma tessitura de memórias de um tempo em que a rapidez, a expertise, a velocidade eram familiares. Eles vivem o achatamento do tempo presente, marcado pelos instantes com as limitações da doença, das agendas das terapias e da espera pela chegada da família, enquanto que o futuro não é mais passivo de planejamentos seguros, uma vez que os eventos de surtos da Esclerose Múltipla são imprevisíveis, como são as possíveis sequelas. Restam as memórias de passados de sucesso, de lembranças que podem compor narrativas de memórias que valem a pena deixar como herança, construtoras de identidades seguras. Nilza se agarra nas lembranças e as tece como se fossem fios desordenados, Ademir organiza uma história simétrica, como desejos de harmonia e ambos fazem ver com suas narrativas um 'outro de si mesmos'.

Ela tenta desesperadamente uma precisão nas marcações temporais para o tecido da sua memória. Exige uma perfeição temporal. Ao narrar sua juventude, o momento em que construiu suas escolhas, desde os namoradinhos da escola, seu noivado, seu casamento, o nascimento dos filhos o fez com desejo de detalhes.

[...] eu tenho tudo na outra pasta onde eu tenho tudo... o negócio da confirmação [...] 14 anos, uhun, sim, sim, sim. É porque, 13, 14 anos (pausa) com 14 anos eu, no caso eu fiz a confirmação na igreja, e logo em seguida, como eu já tinha começado, já estava na escola, 'Germano Tim', onde eu sempre ia também, e lá tinha uns rapazes, eu gostava de uns tão bonitinhos.

E continuou narrando suas escolhas até o noivado com o ex-marido. "Nós noivamos e (pausa) dois de Maio, sei que era dois de Maio. Eu tenho tudo marcado só que não sei se foi em '80', não'. Datas são importantes para Nilza, mas elas escapam. Ela sempre faz referência a um registro anotado em algum lugar. E por vezes movimentou as rodas da cadeira para tentar buscar pastas com folhas, bilhetes, registros, anotações de informações perdidas. 
O nascimento dos filhos foi outro momento em que as marcações temporais se fizeram confusas nas lembranças que apareciam, mas nem por isso menos importantes.

[...] o Jorge nasceu dia 26 de Julho, não é ... o Paulo nasceu dia 26 de Julho eu estava trabalhando. Eu cheguei em casa, isso eu me lembro, eu cheguei em casa, eu tinha que passar tudo a roupa do bebê e ainda e não deu tempo, a bolsa estourou, aí fui direto pra maternidade". A data poderia estar confusa, mas ela compensou com outros detalhes desse momento. "[...] trabalhei até quando eu engravidei do Jorge que foi logo em seguida, foi um ano depois... foi... um ano depois dia 26 do 'sete', um ano depois, dia 2 de Julho que nasceu o meu segundo filho [...] 83, 84...hoje eles têm 31 anos.

Esse tempo passado foi narrado a parir de suas lembranças que ficarão à prosperidade, "o outro de si mesmo" da Nilza, antes da EM - uma mulher ativa, que trabalhava, cuidava dos preparativos para a chegada dos filhos. Por vezes ela dizia "e foi assim que foi". Havia um desejo de verdade, um desejo de precisão. Havia no tecido das lembranças, nas narrativas de memória o mesmo traço do controle da família, da alta exigência daquela empresária que cuidava da produção da facção. A menina linda namoradeira, a jovem rebelde que passeava de moto, o amor apaixonado, a família linda com dois filhos com bochechas cor de rosa, a empresa que logo deu certo e a mulher Nilza no comando. Mas o desejo de verdade era presente e ela não deixou de narrar tensões de família, ressentimentos, comportamentos julgados como erro, arrependimentos. Essas humanidades funcionaram como "chaves" de significação para as narrativas após a EM.

A doença como uma experiência traumática de vida funcionou para Nilza como um marco temporal. Existe uma mulher antes e uma depois da EM, porém, algumas tensões duraram e foram marcantes na forma como as coisas se desencadearam após a doença. E de forma muito especial os desdobramentos a partir das necessidades de dependência do pai e por consequência a perda do marido em situações singulares de tensões familiares. A filha única, superprotegida, não deixou de existir, mesmo que com muito desconforto. A narrativa da separação e divorcio foi marcada por silêncios, desconfortos, mágoas e ressentimentos. É um desdobramento da doença, é um momento em que ela perdeu o controle da sua própria vida e não pode sustentar a ruptura que havia feito. Ao voltar a ser apenas filha, dependente economicamente, o pai decidiu por ela. 
Ao narrar sua trama de memórias na família a Nilza, além de destacar o sobrenome que a liga a uma "origem alemã", constrói outros nós nas tessituras de uma trama que a liga ao passado e ao presente. Relata as desavenças e rupturas com os pais e se arrepende, mas também relata com certo arrependimento sua dificuldade de expressar afetos e carinhos com os filhos quando pequenos, sem perceber as repetições geracionais dos comportamentos. Ela tece, em silencio, um fio que a liga no seu passado e no presente dos filhos quando também compara os comportamentos do filho mais velho com o seu, a dedicação compulsiva pelo trabalho e construção de bens materiais e a sua quase ausência e ruptura com a casa materna.

[...] o meu filho mais velho, ele não tem tempo final de semana, não tem tempo. Porque ele faz isso, faz aquilo, vai fazer cursos, vai fazer pedaladas, coisas assim, pra que a mãe? A mãe está bem, está bom, então é isso. Um tempo eu me chateava muito, estava muito machucada, mais hoje? Não, não me machuca mais... deixa eles viver a vida deles e espero que eles sejam felizes e que um dia não vão se arrepender. O que eu me arrependi já, o que eu fiz com meus pais, mais voltar o tempo não dá.

Ela avança para uma perspectiva de futuro e aponta o que ela não gostaria que os filhos repetissem. Essa narrativa parece ser quase insuportável, mas ela dá sequência justificando a sua agenda de trabalho e lazer. Ainda assim, cria coragem para narrar uma ocasião que ele teria sugerido interná-la em uma casa de idosos.

Meu filho já quis me colocar num asilo. No dia que ele tentou colocar no asilo eu chorei tanto, tanto, tanto que o outro filho que estava em casa se assustou. Aí depois meu filho veio... não mãe, não é assim, não. É isso não quero, 'pô', eu ia na fisioterapia, fazia tudo sozinha, porque eles queriam me colocar no asilo? Aí eu chorei mesmo naquela época me lembro como eu chorei, porque eu podia ter vida aqui fora ainda, foi assim que aconteceu as coisas...

No mesmo dia também comentou brevemente e de forma muito fragmentada, as tensões com a mãe no presente, que são também marcadas pelo sustento econômico. As emoções são permeadas tanto pelas condições de dependência econômica do presente, como também pelas suas emoções como mãe. 
Eu sinto muito que aconteceu comigo, mais eu não posso chegar (pausa) é ela que está me sustentando (pausa) não posso chegar, impor pra ela, eu estava um tempo muito raivosa com isso tudo, estava tudo entalado que, enfiei o dedo, foi aqui mesmo (riu e fez pausa) estava muito (pausa) sentia raiva da minha mãe (pausa) não suportava e agora (pausa) não sei, depois dessa briga forte eu melhorei.

Em sua posição de filha sua narrativa parece mais desconfortável. As frases são curtas e incompletas e separadas por pausas longas. E logo muda de assunto. Nilza não consegue suturar as lembranças com as emoções tão díspares entre amor e raiva em uma narrativa coerente. A sequência da narrativa segue em outra direção:

Tem que seguir em frente, só seguindo em frente pra tu ver as suas dificuldades, fazer, como é que eu digo? fazer alguns processos... (pausa grande) fazer como a gente faz alguma (pausa) propaganda pra... pra "acessibilidade" em Joinville. Como tem o Mario, também, que sempre luta pela "acessibilidade", que é difícil aqui em Joinville, que é, tem coisas que é um absurdo, mais a gente enfrenta tudo.

Ela tentou narrar sua tensão com a mãe no contexto da sua tensão com o filho mais velho, mas não conseguiu. Aqui, não aconteceu falha nas lembranças, como por vezes acontecia durante a narrativa. Nesse momento existiam lembranças que não suturavam na trama de memória que ela desejava. Sua subjetividade de filha parece ser muito desconfortável e os fios mudaram de direção, os nós da tessitura buscaram construir outras texturas. Não mais na tensão da passividade de filha dependente, mas em lugares onde ela já foi atuante - na luta pela acessibilidade. É nos agenciamentos de enunciação que traz que Nilza constrói uma "outra de si mesma".

Já Ademir evocou lembranças mais harmônicas com a família, recebeu a equipe para as seções de entrevistas com muito agrado e direcionava os encontros para a cozinha onde um lanche já estava montado sobre a mesa: café, leite, açúcar, um bolo preparado por ele e os pratos, xícaras, talheres e guardanapos cuidadosamente organizados. Havia detalhes simétricos visíveis naquela organização e isso já falava muito sobre aquele homem que iria narrar suas memórias. Suas narrativas também foram simétricas, harmoniosas, sem tensões aparentes, como a cor azul que ele evocou e relacionou ao afeto quando lembrou da mãe. Havia um desejo de perfeição harmônica. Seus passos vacilavam e com a ajuda da 
bengala sentava à mesa. Muito sorridente e agradável se punha a falar. Suas experiências vividas naquele presente direcionam as reelaborações da memória sobre o passado. Assume-se um local de releitura do passado bastante marcado pelas emoções da perda, ou melhor, pelo medo de limitações físicas das mais diversas, mas a cadeira de rodas foi o grande medo revelado. Ademir diz ser agradecido porque considera que suas limitações não são as piores. Ele tem medo da dependência da cadeira de rodas, mas diz também ser muito esquecido, mas em nenhum momento a sua narrativa vacilou por conta dessa sequela. Em uma das entrevistas havia perdido a bengala, mas as narrativas não falharam. Era como se sua história já fosse ensaiada antes da entrevista. Reclamou também da perda da sensibilidade nas mãos, mas isso ainda não o atrapalha no manuseio dos utensílios da cozinha.

Ademir diz "eu penso muito no futuro, aí no futuro, eu ficava sempre pensando que o pior ia acontecer pra mim" e esse pior seria a perda da pouca mobilidade que ainda tem. Refere-se a Deus quando fala desse futuro. "Depois que eu fiquei sabendo da Esclerose eu me apeguei mais com Deus, e mudou bastante, bem diferente, isso que está dando mais forças para enfrentar, pra não desanimar". Em uma outra seção de entrevista, Ademir elabora diferente sua não definida relação com o tempo futuro. Ele diz:

Não consigo me imaginar no futuro, eu só sei que eu quero me cuidar hoje para no futuro eu estar bem. Eu não penso assim na questão financeira, se eu vou estar bem financeiramente, devia de pensar, mas eu não penso assim, Só quero saber do presente [...] eu quero cuidar de hoje mas aí para o futuro. Não sei o que vai ser de mim no futuro. Eu tenho de cuidar bastante hoje.

Nesse momento sua fala foi muito reveladora porque o assunto era o futuro e espontaneamente Ademir trouxe a "questão financeira" para a tessitura da narrativa, como se fizesse parte do assunto, necessariamente. Mas ela apareceu no negativo, "eu não penso assim na questão financeira", mas foi exatamente nela que pensou quando perguntado sobre o futuro, mesmo sem perceber. $O$ que significa o conforto financeiro para aquele homem com uma doença que lhe tira a força de trabalho? Mesmo negando, agradecendo o conforto modesto que desfruta, mas foi o que visitou suas memórias quando perguntado sobre o futuro. Que fantasmas lhe aparecem quando ele relata que comumente sofre com depressões. Mesmo que imediatamente diz que 
nos últimos anos essa questão parece ter se resolvido, narra momentos difíceis em que o medo do futuro lhe assusta.

Ele quer contar sobre um tempo em que era ágil, forte, mas restam as poucas memórias de passados com esse tipo de sucesso, de lembranças que podem compor narrativas de memórias que valem a pena deixar como herança, construtoras de identidades seguras. "É assim ó, quando eu vou ali fora no quintal arrancar matinhos, parece que lá eu penso em tudo sabe? Vem muita coisa na minha cabeça, por causa do passado, sempre do passado". São nos momentos de espera, nesse presente que passa lento enquanto está sozinho em casa, que Ademir cuida dos detalhes da casa, do quintal, do jardim - o produto do seu projeto de vida que ele construiu quando ainda tinha um pouco mais força, sua casa, o acolhimento da sua família -, e enquanto cuida desses detalhes, se alimenta com suas lembranças desse passado.

São poucas memórias dessa época saudável porque desde que se entendeu como um rapaz, economicamente independente, que sentiu que era potente para produzir, fazer funcionar um projeto de um próprio negócio, experimentou namoricos, uma grande paixão que o levou a casar, logo iniciaram os sintomas que o levaram ao diagnóstico da EM dez anos depois. Essas lembranças acerca da doença marcaram o ápice da sua juventude. Ele busca as lembranças da "Discoteca Alvorada", das namoradas, da “época de beijar". Não se acha vaidoso, mas defende que o cabelo deve ser sempre penteado. "A pessoa tem que cuidar bem do cabelo. Sempre tem de estar bem penteadinho”. Mas é difícil para o Ademir narrar esse tempo sem que as lembranças da doença cruzem a narrativa. Ao falar sobre como se arrumava para sair aos finais de semana, o perfume que gostava de usar, corta a narrativa para dizer sobre o presente, quando seu olfato está muito mais sensível. "O perfume me sufoca", a percepção parece ter ficado mais aguçada depois da EM.

Ademir começou trabalhar com 15 anos contra a vontade de seu pai que gostaria que ele terminasse os estudos primeiro. "Via os colegas que eram mais velhos que eu e que trabalhavam. Tinham seu dinheiro, aí eles compravam roupa, boné, e compravam assim todo mês as coisinhas deles, né? Eu também queria”. Iniciou o trabalho em uma metalúrgica, foi demitido e foi trabalhar em uma autopeças onde se realizou. "Ali era muito gostoso de trabalhar, sabe? Era assim um comércio, trabalhar com o povo, gosto muito. Gostoso vender peça de carro, ali eu trabalhei de 
1991 até 1996". E no meio de uma lembrança do tempo saudável novamente um corte veio - a EM mudando os rumos da sua vida. "E foi em 1994 que eu casei, estava trabalhando ali na autopeças, esse meu patrão era muito gente boa, foi no meu casamento [...] em 1996 tive meu primeiro surto [...] deu esse surto que eu nem sabia o que era um surto né?"

Sua narrativa acerca desse passado saudável vem sempre atravessada pelos sintomas da doença. Ele faz ver com sua narrativa um "outro de si mesmo" muito próximo das características que admira em seu pai. Sobre os tempos difíceis ele se emociona, mas em seguida narra sua vida da seguinte forma:

Mas graças a Deus passou. E hoje é por isso que eu agradeço e muito a Deus. Dobro meu joelho à noite e agradeço a Deus. Foi difícil, foi muito difícil, mas passou. Hoje eu estou bem acomodado, estou bem confortável, no ar condicionado, numa cama maravilhosa, colchão bem bom [...]

Sem perceber, ele repete a qualidade que elogiou no pai, "nunca reclama de nada". Ele tece com esse fio que se liga a geração anterior na família, uma "totalidade provisória de passado" (CANDAU, 2011). Religioso como diz ser toda a família, percebe-se depois da doença mais apegado à igreja e no momento da entrevista narrou que junto com a mulher vai à missa todos os domingos, além de participar das atividades católicas. Seria esse um hábito que não lhe permite reclamar? Ele admira no pai e deseja para si? Ele quer trazer as boas lembranças, constrói uma textura para sua narrativa sem muitos impactos ou tensões. E não se permite o tom mais dramático na narrativa, ainda que os dados trazidos justificassem. Ao trazer falas de gratidão por um presente seguro e estável funcionou como um "conserto" por ameaçar a harmonia de sua história.

Enquanto narrava, Ademir apresentava um corpo tenso, por vezes suas pálpebras tremiam, suas mãos eram tensas, seus olhos azuis eram observadores e sempre havia um sorriso. A casa era impecável, apesar dele pedir para ninguém reparar, o cabelo impecável, a mesa posta de forma simétrica, a imagem da família trazida na narrativa, tudo cuidadosamente tecido como se fosse um presente para um Outro. O desejo de memória parecia ter endereço, e tinha. Existia uma gratidão pelo tempo presente e a certeza de que os tempos ruins foram superados, embora o medo de que eles possam voltar seja um fantasma. Mas, essa 
gratidão é dedicada à mulher, a narrativa harmoniosa que Ademir construiu era um presente para a mulher, a "esposa amada", como preferia dizer. Mas, por quê? O que levou Ademir a decidir que a história de sua vida pudesse ser dedicada à sua companheira? Ele se narrou, em um momento antes da EM, com poucas palavras e detalhes, como um homem seguro demais "Eu me achava o 'bonzão". E quando perguntado sobre momentos de brigas de casal ele sorri, pensa na resposta e brevemente diz "olha, acho que teve". Eram tempos de algumas brigas de casal por "ciúmes bobos", segundo ele. "Aí depois que eu fiquei sabendo que tinha esclerose [...]" ele narra com mais palavras e detalhes a mulher que lhe "abraçou com as duas mãos". Desde então, é ela a grande companheira. Quando da construção da casa, momentos de muito estresse, muitos sintomas, sem diagnóstico e ele diz "a gente fazia tudo pra adquirir mais dinheiro e terminar isso logo. Daí trabalhava o dia inteiro, ela também, as minhas filhas ficavam com a vizinha”. Quando falou do orçamento doméstico novamente é ela que vem na narrativa "Ela sempre foi muito parceira [...] eu recebo meu pagamento ela recebe o dela [...] a gente é bem generoso um com o outro". E novamente ele talvez não perceba, mas repete a imagem que narra do seu pai e sua mãe, de uma vida juntos, de companheirismo, como se houvesse um fio de memória na família que lhe garantisse uma segurança.

Esse tempo passado foi narrado a partir de suas lembranças que ele entrega ao futuro, deixa a prosperidade, "o outro de si mesmo" do Ademir, antes da EM - um homem ativo, seguro de si, que trabalhava, cuidava dos preparativos para a construção de uma família. Havia um desejo de harmonia o tempo todo, um desejo de gratidão. Havia no tecido das lembranças, nas narrativas de memória o mesmo traço estético da família, da alta exigência daquele funcionário que depois se transformou em empresário. O rapaz bonito de olhos azuis, que pedalava quilômetros de bicicleta, passeava de moto, o amor apaixonado, a família quase "perfeita" com duas filhas. A doença como uma experiência traumática de vida também funcionou para Ademir como um marco temporal. Ainda que o roteiro da entrevista tenha direcionado uma narrativa a partir da idade cronológica da vida, mas ele rompeu o tempo na narrativa e destacou um outro de si mesmo que nasceu a partir da EM. Porém, alguns valores de uma eclusa de tempo anterior à doença, aprendidos na família duraram e foram marcantes na forma como as coisas se desencadearam após a doença. 


\title{
1.3 Outros de si
}

Nas análises das narrativas de memória de Nilza e Ademir, foram observadas três instâncias da construção das "subjetividades políticas" distintas. Em um primeiro momento, Nilza era muito certa do controle da sua vida, com o seu mundo significado à sua volta, sente os primeiros sintomas:

Primeiro sintoma foi quando fui que eu emagreci e eu, na flor da idade, praticamente meus 30 anos cheguei toda boba (com o emagrecimento). Trabalhava ainda tudo, e foi onde que eu emagreci, ai fui num neurologista e o neurologista simplesmente falou pra mim que era só estresses. Ele me deu uns calmantes lá e ficou por ali. Não levou muito tempo fui pro pronto socorro por que cai de novo. Eles começaram a me dar corticoide. Dando corticoide eu melhorei, fiquei seis meses melhor. Normal, andando fazendo tudo, trabalhando normal. Depois deu mais um "surto", aí eu como estava com uma 'firma' que eu formei na minha garagem, eu tinha bastantes funcionários e eu tive que ... (mudou de assunto) peguei tomei outra vez esse corticoide por alguns dias.

No segundo surto Nilza desvia a narrativa para o trabalho, ela tinha os funcionários, como fazer? Ela não termina a frase e toma outra digressão. Um momento de infância, de não dar conta com palavras os signos à sua volta. Uma grande novidade ainda não nomeável, apenas sentida.

\begin{abstract}
Aí tomava ficava bom de novo, estava como diz, show de bola. Bom, tenho uma firma e funcionários eu vou continuar! Passaram quatro meses, deu outro "surto", aí eu comecei a procurar, quem? ... quem ia procurar? "Não! está com pé inchado, chato" diziam. Fui num ortopedista, ele disse que não era com ele e me encaminhou a um neurologista. Foi onde que eu fui pro neurologista, mais como se eu já tinha ido no neurologista antes?
\end{abstract}

A procura pelo diagnóstico é um momento muito dolorido. Não existe explicação para os sintomas e eles são agressivos. Para Agamben (2005), como já visto, a infância não seria um tempo cronológico na vida dos homens e das mulheres, seria na verdade uma tentativa de pensar o problema dos limites da linguagem. O tempo anterior ao diagnóstico da doença oferece momentos dessa "morada infantil" do 
puro signo. Ainda que haja uma imensidão de informações acerca da doença, ainda que essas informações interpretem em grande medida o vazio que produz o diagnóstico, há um luto indecifrável, um momento de infância com a ausência de tradução.

Com Ademir esse momento de infância durou 10 anos. Ele narra o vazio de experimentar os sintomas da Esclerose Múltipla por dez anos sem nenhum diagnóstico, ou diagnósticos equivocados e, por consequências, tratamentos sem sucessos. Um momento de vazio do quase puro signo. Ademir se entendia como um homem jovem que gostava de se locomover de bicicleta pela cidade, se entendia ágil. E quando os sintomas chegaram não eram codificados, ele narra um desses momentos:

\footnotetext{
Eu tinha muita queda sabe. Eu adorava andar de bicicleta, adoro, adoro, adoro. Eu trabalhava eu já morava aqui no Espinheiros, então até o local do meu serviço eram cinco quilômetros de distância. Eu tinha na época um Chevette, mas não ia de carro trabalhar. Eu tinha uma moto também e deixava a moto em casa. Deixava o carro em casa e ia trabalhar de bicicleta. Só dia de chuva daí ia de carro. Ia de bicicleta de tanto que eu gostava de andar de bicicleta. Aí comecei a cair, cair de bicicleta, perdi o equilíbrio... eu estava pedalando aí se eu estivesse pedalando, se eu olhasse um pouquinho pro lado eu perdia o equilíbrio e caía. Isso foi várias vezes! Várias vezes! Não podia olhar nada pro lado que eu perdia o equilíbrio e caía. Tinha que olhar só pra frente, ter visão fixa assim pra frente.
}

Interessante que ele narra o sintoma do passado, mas não mantém os verbos somente no passado. "Eu adorava andar de bicicleta, adoro, adoro, adoro". Esse detalhe parece ser apenas um detalhe, mas perceber um processo de subjetivação no tempo torna essa forma de linguagem bastante importante. O que foi o seu passado de força e agilidade ainda dura no seu corpo de alguma forma e, ainda que seus passos precisem de ajuda de uma muleta, mas locomover-se a partir da força física parece ser algo potencial naquele corpo. $\mathrm{O}$ argumento racional da narrativa para justificar esse gosto foi econômico, ou seja, apesar de ter um carro e uma moto, preferia a bicicleta. Como explicar as quedas repentinas? Como explicar desequilíbrios na ciclovia? Como explicar não conseguir levantar-se de um tombo? Um momento de "infância" com um signo insignificável. Ademir entrou no fluxo desse agenciamento coletivo de enunciação e se subjetivou de uma outra forma. Entendendo-se como um homem como ele disse "bonzão", sabia da sua capacidade e 
munindo-se dessa certeza e do sonho de ter o próprio negócio, pediu demissão e abriu uma empresa - uma loja de auto peças.

O primeiro surto trabalhava com esse mesmo "Tim" e fiquei ali trabalhando com ele, estava com esclerose mas não sabia. Pedi a conta e montei um negócio pra mim. E não sabia que era esclerose múltipla e bateu mais um surto. Daí não estava bom... bateu aquela depressão danada! Não sabia o que eu tinha, emagrecendo, não conseguia dormir, não conseguia comer... Uma situação muito difícil.

E diante da pressão e dificuldades, narrados por Ademir como vivencias típicas da vida de um pequeno empresário, sentiu que seu corpo não dava conta daquele sonho. E sem explicações para os sintomas físicos que colaboraram para seu ao fracasso, vendeu a loja, voltou a trabalhar como empregado e se deprimiu. Em um tempo antes, ainda como funcionário da primeira auto peças, foi diagnosticado como "micro infartos".

Era "micros infartos" [...] aí tá, mais remédio né? mais remédio! E nada de passar também, nada. E trabalhando sempre. Mais eu ia trabalhar só que não era a mesma coisa, era diferente, eu não tinha mais o equilíbrio. Eu sentia! Eu não era mais ágil, não ia mais rápido na prateleira buscar peça, eu não tinha mais equilíbrio pra subir em escada, em escadinha dessas de cinco degraus, eu não conseguia mais ir lá no segundo andar pra subir naquelas escadas. Não subia mais rápido! Pra descer era pior ainda, não tinha o equilíbrio e aquilo estava, sabe... aquilo me dava angustia porque eu via os meus amigos eles eram tão ágeis e eu não era mais igual a eles.

Como ligar com essa impotência frente a outros homens? Que nome davam para essa falta de destreza de um homem aparentemente normal? "Eu sentia!". Era apenas sentido, e não havia explicações que dessem conta daquele signo. "Micro infartos" foi uma tentativa, mas o prognóstico não funcionava. Como sentia sua masculinidade em relação aos outros homens? Ademir narra episódios em que derrubava peças no chão e todos riam, o chamavam de bêbado. Mas diante da ausência de palavras que explicassem aqueles sintomas, ele, a família, os colegas e até mesmo os médicos aproximavam metáforas para significar seus sintomas: labirintite, "micro infartos", bebida. Tentativas desesperadoras de significação para Ademir! 
Na história de Nilza o diagnóstico veio mais rápido e ela, sem acreditar, procurou um segundo profissional que a confirmou: ela precisaria viver a partir daquele momento com a Esclerose Múltipla. Naquele momento da história da doença, na década de 1990, a medicina não dispunha de medicações que pudessem ao menos amenizar o desenvolvimento da doença. São agenciamentos coletivos de enunciação que nomearam seus sintomas e diante do pouco que se sabia sobre a EM, algo ficou - é uma doença degenerativa, progressiva, incurável e com potencial incapacitante. Diante do luto que se instala, da solidão da experiência com os limites irreversíveis Nilza procurou socorro: "e dali que começou minha luta... querendo uma cura pra mim, aí vai lá, massagem faz bem, aí fui nos lugares que fiz massagem, mais nada adiantava.”

Uma mulher ativa, com pouco mais de 30 anos, empreendedora, procurou ajuda institucional, com seus semelhantes. Onde estavam os enunciados coletivos que pudesses ser consumidos e que dessem conta desse vazio instaurado?

Nos primeiros dias eu ia na "ADEJ" (Associação Deficientes Físicos de Joinville), aí eu participava muito com eles lá e passou o tempo assim e aí na "ADEJ" tinha um... ele era de um laboratório. Ele era... como é que você diz aquele pessoal quem vem fazer, quem vem no médico faz a ... representação. Ele era representante.

Nilza se aproximou das informações sobre sua nova condição. Ela se assujeita a essa nova condição a partir da sua história antes da EM. Ou seja, foi-se constituindo uma nova subjetividade a partir da EM, mas com as ferramentas que ela tinha antes da doença. Esse assujeitamento aos enunciados que deram sentidos a sua condição, esse consumo de informações, modos de vida, opiniões acerca das deficiências não significa apenas uma aceitação passiva. Nilza logo se propôs a criar uma associação de apoio aos pacientes de EM em Joinville e região e se orgulha disso. Foi uma criação possível apenas a partir da experiência com a EM e dos consumos dos enunciados coletivos de enunciação em que ela estava inserida. Existiam agenciamentos de enunciação dos laboratórios e dos médicos que foram consumidos, mas havia também um momento de criação de um novo enunciado - a Associação de Apoio aos pacientes de Esclerose Múltipla de Joinville e região, (ARPEMJ). 
mais eu preciso de apoio de vocês. Ah não tem problemas. O Dr. Alexandre me passou alguns dados de pacientes que tem esclerose. Fiz a famosa reunião, foi bastante... bastante como é que é? ... bastante... tinha bastante (a memória falha) propaganda, anúncios, e tudo, eu fiz uma coisa bem legal mesmo.

Nilza se orgulha desse momento. Ela criou a associação de apoio aos pacientes de Joinville e região. Aquela empresária exigente que controla a própria vida brilha nos seus olhos e a menina dependente dos pais se acalma. Ela disse que nesse momento "se sentiu muito bem".

Apoios eu tinha bastante, aí foi onde que, eu fui me concretizei [...] Esse mesmo representante falou: ah tu quer fazer uma associação, então eu vou te mandar pra São Paulo. A Beatriz que era minha fisioterapeuta foi minha acompanhante.

Nilza se juntou a uma rede com sua criação e sua subjetividade foi se transformando a partir dessa potente criação. Ela não é mais apenas aquela filha que foi submetida a partir das condições que lhe formam impostas, mas a partir delas fez um outro caminho.

O diagnóstico pode significar para muitos uma grande confusão, afinal, se descobre que nada será como antes e para Nilza funcionou como um momento de luto. Mas para Ademir foi o grande alívio que ele buscava. "Essa época foi uma sensação de alívio! Ba! graça a Deus acharam o que eu tenho! Porque até então eu vivi de 1996 até 2005 naquela incerteza, tratando de doenças, tomando remédios sem saber o que tinha. Vivia caindo! Vivia tonto!"

A partir do enunciado sobre a doença, Ademir se aproximou das informações sobre sua nova condição, especialmente a partir da associação que Nilza criou. Havia possibilidades de colocar palavras naquele vazio. Ele se assujeita a essa nova condição a partir da sua história antes da EM. Voltou mais ativamente para a igreja, agradece pelas possibilidades, assumiu suas fragilidades, afinal elas têm nome e explicação. Esse assujeitamento aos enunciados que deram sentidos a sua condição, esse consumo de informações, modos de vida, opiniões acerca das deficiências não significa apenas uma aceitação passiva.

Mas esses enunciados médicos, não só significaram os vazios para Ademir como também o impulsionaram a novas direções. Usando os conceitos de Guattari e Rolnik (1999), ele torna-se parte de novos agenciamentos coletivos de enunciação. Ele se subjetiva a partir desses 
enunciados que lê nos materiais produzidos pela associação, pelos médicos e sites especializados, mas especialmente a partir de significações acerca da agilidade física que são caros a ele desde antes do diagnóstico. Ou seja, os enunciados acerca da EM o assujeita, mas o quê desses enunciados tem a ver com o Ademir antes deles? Sua singularidade foi narrada a partir do que provocou os enunciados relacionados ao potencial incapacitante da EM. Ele conta como se aposentou:

Em 2005 fiquei sabendo que era esclerose múltipla e me aposentei dia 17 do sete de 2007. Aposentado por invalidez! [...] Até é uma palavra que eu não gosto, invalidez, né? Uma palavra tão feia! Mais essa palavra não combina comigo. Eu acho que não combina comigo! Porque eu tenho grande serventia nessa casa, tanto pra minha mulher quanto para as minhas filhas. Mesmo assim eu consigo roçar o gramado no jardim, limpo minha casa, faço comida, do meu jeito na minha velocidade. Mas faço! Então, eu não me considero um inválido.

E nesse momento da entrevista ele fez uma pausa e ofereceu um café. Mudou de assunto! Estava decidido, não existe invalidez para o Ademir. Mas, enquanto processo de subjetivação, foi esse enunciado médico e jurídico que o autorizou a se aposentar. Esse foi o argumento que o tirou do trabalho produtivo, da lógica do mercado, dos esforços desumanos para quem sofre com os sintomas da EM. Mas Ademir não se assujeitou a essa "identidade" para sempre. Como se reinventou? "Tenho grande serventia nessa casa, pra minha mulher e para as minhas filhas.” É no espaço mais comum, mais privado, mais ordinário, que Ademir se reinventa.

No primeiro movimento do processo de subjetivação ambos, de uma forma ou de outra, permanecem submetidos a agenciamentos coletivos de enunciação tal como os recebe, assumindo a "alienação e opressão", como também proposto por Guattari e Rolnik (1999). No segundo movimento, eles se reapropriam dos componentes da subjetividade, valendo-se da expressão e da criação, e vivem o "processo de singularização". Esses dois movimentos são intercambiáveis em um mesmo corpo e "duplamente descentrados". Como já anunciado na primeira parte desse artigo, existe descentralização constante, quando pode acontecer um segundo movimento - "processo de singularização". De forma imanente ao "processo de subjetivação" as singularizações são as próprias raízes produtoras da subjetividade em sua multiplicidade. 
Seria, ainda, a utilização da potência humana de negociar sentidos no limiar da privação da língua, no local das tensões entre o signo e a semântica, entre o saber e o movimento da história.

Ademir de assujeita também aos agenciamentos coletivos de enunciação mais comuns na esfera da vida doméstica onde ele passa a maior parte do seu tempo - os programas televisivos de culinária. No fluxo desses agenciamentos ele aprende a testar receitas na cozinha, e enquanto espera a família vai cozinhando, quando fala de seus momentos de depressão ele diz:

estou cozinhando bastante aí me distrai [...] eu assistia aquele programa da Record, aquele Hoje em Dia, não sei se já ouviram falar, que tinha programas de receitas culinárias, daí foi onde eu comecei a pegar também, comecei a me interessar por fazer almoço, fazer aquelas receitas gostosas, enfim que minha mulher se agradava disso, gostava, ai gostava de fazer, e todo mundo gostava que eu fazia (risos).

Deprimir-se é um sintoma de assujeitamento a enunciados acerca das limitações, é aceitar a impotência. E Ademir experimenta esses movimentos de subjetivação também, mas não somente, ele se reinventa usando os mesmos agenciamentos coletivos dos espaços pelos quais foi submetido a partir da aposentadoria por invalidez. Importa nessa análise o que ele faz com os desdobramentos do enunciado "invalidez". Ademir narra um cotidiano da família onde ele se fez fundamental. Ele diz:

Eu venho fazer o café da manhã, arrumo a mesa, vou chamar a minha esposa pra tomar café comigo, a gente gosta de tomar café juntos, adoramos tomar café da manhã! Café da manhã é essencial! É sagrado! A gente gosta de tomar café da manhã juntos! [...] Adoramos! Tem que ter a tapioca com salgado, depois uma tapioca doce, ou quando não tem a tapioca vai o pãozinho integral. É que eu faço integral né? Só que antes do café tem que comer um mamão, o café leva no mínimo... no mínimo, uma meia hora. Bem tranquilo... melhor refeição do dia! E depois começa os "corre"...

É ele que garante às filhas e à esposa o momento de prazer à mesa. E se sente satisfeito enquanto narra o café da manhã da família. Lembra que antes da EM não era assim, era muito trabalho, muita correria e a família não sentava à mesa. Sente-se orgulhoso por manter esse conforto e continua a narrativa de reinvenção: 
Aí muitas vezes eu faço almoço à tarde já pro outro dia. Não é sempre né? muitas vezes quando é um almoço mais demorado. Aí só fica pra ela [a esposa] fazer a salada, que ela faz uma salada assim bem caprichada sabe, vai vários tipos de salada, tudo num "tapawere" só. Faz uma salada muito gostosa, muito caprichada e põe orégano, salsinha, cebolinha verde, fica muito caprichada. Isso ela faz. Mais aí o resto é comigo. [...] E eu tento deixar o máximo de carinho na carne pra ela levar [na marmita], às vezes um macarrão, feijão, tipo de arroz, procuro caprichar também né. Às vezes no bolo que eu faço.

Esse esforço garante ao Ademir um "outro de si mesmo", é nesse lugar que ele se reinventa. No mais ordinário dos lugares - o doméstico - ele faz o seu reino! Torna-se e sente-se imprescindível para as filhas e para a mulher. Garante uma estrutura doméstica que convencionalmente se tem na figura feminina, mas Ademir toma esse lugar como seu! E no movimento de subjetivar nos fluxos de agenciamentos coletivos de enunciação e se singularizar a partir deles, ele vai se reinventando no espaço da cozinha. Isso não significa que superou sua condição, ele continua com os mesmos sintomas todos os dias, continua vez ou outra com depressão, ainda sente medo do futuro, continua caindo. "acho que faz uns 60 dias, eu caí bem na frente dessa geladeira ali. Eu estava muito cansado muito fatigado, daí meu pé não levantou mais... o pé esquerdo. Daí tropecei e dei com a cara assim no chão, cortou meu lábio por dentro, quebrou um dente. Foi a última queda". Porém agora, luta contra a invalidez, negar esses enunciados é seu desejo de potência, agora ele faz parte de um fluxo de agenciamentos coletivos de enunciação e se reinventa com toda humanidade própria dos homens ordinários.

\section{Reflexões provisórias}

Ademir e Nilza foram envolvidos em agenciamentos coletivos de enunciação da fala médica científica sobre seus sintomas que em síntese diz: "a EM é uma doença rara, é degenerativa, progressiva, incurável e com potencial incapacitante". Ainda que um enunciado dessa natureza seja inspirador para um luto irreparável, como foi para Nilza, para Ademir foi como um balsamo que apaziguou suas aflições com a experiência de sentir os sintomas sem nome. Ela trouxe um desenho ao vazio de significação para seus sintomas com esse enunciado médico. Nilza procurou grupos semelhantes a ela, se aproximou dos 
representantes de laboratórios soube da instabilidade dos surtos, da ausência do marcador biológico.

A partir do envolvimento com esses enunciados e com a experiência diária com algum tipo de debilidade, as narrativas de suas memórias vieram recheadas de momentos de gratidão e de desejo de uma história esteticamente perfeita, sem ruídos, com o mínimo de drama e sofrimento possível. E quando eles eram inevitáveis, Ademir voltava ao presente para reforçar que tudo passou e agora se sente grato pela sua condição.

Nilza constrói uma narrativa de suas memórias recheadas de momentos entre negação completa, especialmente quando o diagnóstico se desdobrou no divórcio, depressões, busca de informações e por vezes busca pela cura, adaptações com os limites, dependência de uma cuidadora, buscas de autoconhecimento, criações de artesanatos de tear e, por fim, uma necessidade muito grande de registrar anotações que podem ser perdidas, porque um dia poderão fazer parte de uma história de si. Sua habilidade de sequência, também comprometida pela EM, a impede de organizar tantos registros, mas estão lá, em algum lugar em tantas pastas para auxiliar suas lembranças.

Em algum momento suas histórias encontraram o limite corporal em que o "eu" procura reconhecer-se a si mesmo com a EM e se depara com algo irreversível, irreparável - a cadeira de rodas, a muleta, a perda da destreza das pernas, sequelas relacionadas à memória e desconfortos com a fadiga, sono e um luto da expertise e da rapidez em que se conhecia. Mas apenas por não se reconhecerem nesse novo corpo que recebeu o enunciado de "inválido" para o trabalho, nesse luto diário, ambos construíram algo que só foi possível na relação com a doença e com o próprio limite - um outro de si mesmo, ou no espaço público com a criação da associação ou no espaço privado nos afazeres com a família, na estrutura da casa. Esse momento se apresentou como libertador em ambas narrativas!

Comumente, os enunciados que chegam aos pacientes, pelos laboratórios, pela mídia, são comuns os exemplos de "superações". E esses agenciamentos de enunciação acabam sendo repetido pelo paciente. Durante essas análises dos processos de subjetivações tanto da Nilza quanto do Ademir argumenta-se a favor de que não existem superações nesses atos. São criações a partir dos enunciados sobre a doença, mas também a partir da experiência com os limites corporais 
que a doença impõe e os medos acerca dos limites possíveis ao longo da vida. Um dos efeitos comuns dessa experiência é a mudança no horizonte de expectativas, na subtração da ilusão de que seria possível algum sucesso nos planejamentos de futuros. A doença infere na sensação temporal presente/futuro e intensifica o desejo pelas narrativas presente/passado. Em alguma medida esse deslocamento nas sensações temporais permeia as subjetividades construídas a partir dos enunciados sobre a doença. $\mathrm{O}$ projeto de ser passa a se realizar no presente, ou no único tempo que se tem, já que o passado é seguro, mas não volta e o futuro é improvável e inserto. Existe uma experiência temporal comum entre eles? Em certa medida sim. Esse "outro de si mesmo" se faz ver a partir das narrativas tecidas entre memórias do passado, presentes reinventados e futuros temidos. Por essa razão, a superação não acontece. Não existe algo a ser superado para se transformar em passado amanhã e seguir um futuro digressivo totalmente liberto. Os limites com a EM são diários, ainda irreversíveis e nunca superados. E exatamente nesse ponto insuperável está a potência da criação que não funciona para o futuro, mas para um presente. É como uma vontade de potência que funciona apenas no tempo presente, enquanto houver limites insuficientes para parar.

\section{Referências}

AGAMBEN, Giorgio. Infância e História. Destruição da experiência e origem da história. Belo Horizonte: UFMG, 2005.

ARFUCH, Leonor. O espaço biográfico: dilemas da subjetividade contemporânea. Rio de Janeiro: UERJ, 2010.

BAUMAN, Zygmunt. Identidade: entrevista a Benetto Vecchi. Rio de Janeiro: Jorge Zahar, 2005.

BOURDIEU, Pierre. L'illusion biographique. Actes de la Recherche en Sciences Sociales. Junho 1986.

CANDAU, Joël. Memória e Identidade. São Paulo: Contexto, 2011.

COUTO, Mia. O apocalipse privado do tio Gueguê. In: , Cada homem é uma raça. São Paulo: Cia das Letras, 2013. 
DOSSE, François. O desafio biográfico. Escrever uma vida. São Paulo: USP, 2009.

GUATTARI, Félix; ROLNIK, Sueli. Micropolítica. Cartografias do desejo. 5. ed. Petrópolis: Vozes, 1999.

HUYSSEN, Andreas. Seduzidos pela memória: arquitetura, monumentos, mídia. Rio de Janeiro: 2000.

KOSELLECK, Reinhart. Estratos do tempo. Estudos sobre História. Rio de Janeiro: Contratempo, 2014.

MARDER, Herbert. Virginia Woolf. A medida da vida. São Paulo: Cosac Naify, 2011.

MULTIPLE SCLEROSIS INTERNATIONAL FEDERATION. Atlas da Esclerose Múltipla 2013. Mapeamento da Esclerose Múltipla no mundo. Tradução Associação Brasileira de Esclerose Múltipla. London: Multiple Sclerosis International Federation, 2013.

POULOT, Dominique. Uma história do patrimônio no ocidente, séculos XVIII-XXI: do monumento aos valores. São Paulo: Liberdade, 2009.

RICOEUR, Paul. Memória individual y memória coletiva: rememoracion y conmemoracion. In: RICOEUR, Paul. La lectura Del tiempo pasado: memória y olvido. Madrid, Arrecife, 1999.

SANTOS, Boa Ventura de Souza. Discursos sobre as Ciencias. 5.ed. São Paulo: Cortez: 2008.

THOMPSON, Paul. Histórias de vida como Patrimônio da Humanidade. In: WORCMAN, Karen; PEREIRA, Jesus Vasquez. (Coord.). História falada: memória, rede e mudança social. São Paulo: SESC; Museu da Pessoa; Imprensa Oficial do Estado de SP, 2006.

Recebido em 25/10/2015

Aprovado em 30/12/2015 